this type there is not room for great detail and one might have liked, for instance, to see more stress laid on the frequency of ante-natal examinations in the latter half of pregnancy, some reference to the teaching of relaxation in preparation for childbirth, and some other obstetric points but, on the whole, the book is very comprehensive. The use of pyridoxine and the anti-histamine drugs in hyperemesis gravidaum is omitted and so is a description of haemorrhagic disease of the newborn.

The gynaecological section is perhaps better than the obstetric and the method of taking gynaecological symptoms and setting out their causes, investigation and treatment is excellent. Probably in no other book can the harassed practitioner so quickly find a concise and comprehensive guide when faced with a patient presenting a symptom such as leucorrhoea, pruritus vulvae or sterility.

The lay-out of this book is, in fact, its chief recommendation. The clear headings, concise notes on important facts and theories, complete differential diagnosis and definite advice as to treatment make it a most excellent book of reference. Very little is omitted, perhaps in some sections almost too much has been included, but it is difficult to draw a line between essential and non-essential information, and, generally speaking, the knowledge of theories of causation in obstetrics and gynaecology is essential if examinations are to be passed.

Not only students but hospital residents and general practitioners will find this book invaluable. As the author says, its main purpose is for quick revision of a subject previously or simultaneously studied in a larger text book, but many busy practitioners find such a concise approach to a subject of much more value than the more lengthy and sometimes confusing detail of conflicting opinions found in the larger works, and will therefore find this book of greater service.

\section{EYE SURGERY}

By H. B. STallard, M.B.E., M.A., M.D., F.R.C.S. 2nd Edition. Pp. xiii +667 , with 550 illustrations. Bristol: John Wright \& Sons. 1950. £2 I2s. 6d.

The appearance of a second edition of this book within four years of the first is itself evidence of its value to students of ophthalmic surgery.

Whilst the individual character of the work, with its advocacy and detailed description of the techniques employed by the author and its emphasis on traumatic and reconstructive surgery has been retained, a number of valuable additions have been made. These concern, in the main, such surgical methods as scleral resection, gonitomy and keratoplasty and include also a description of the operation of basal iridencleisis which the author has recently introduced for glaucoma.

Useful paragraphs on the employment, as adjuncts to surgery, of amniotic membrane, fibrinogen, thrombin, penicillin and sterile air $\bar{z}$ appear in appropriate sections. The text is notably $\stackrel{\varnothing}{\varrho}$ aided by the addition of some 200 new illustrations. $\subseteq$ H.E.H.

\section{THE LAW AND ETHICS OF DENTAL PRACTICE}

By R. W. DURAND, M.R.C.S., L.R.C.P., and $\stackrel{\triangle}{\perp}$ D. Morgan, L.D.S. Pp. vii +98 . London : English Universities Press, Ltd. 1950. 7s. 6d.

Into this small volume the authors have compressed adequately the law and ethics of dental practice affecting the dentist in his relationship with his patients, his colleagues and his employees.

This field has aldready been covered by Edward Samson and S. L. Drummond-Jackson as far as private practice is concerned and the book would have been rendered much more valuable and far more attractive to those dentists, comprising 'ninetenths of the profession, who practise under the Dental Regulations of the National Health Service Act, if some space had been devoted to explaining their contractual obligations to their State patients and to their Local Executive Councils under the regulations.

This is the more to be regretted as one of the $\underset{\mathbb{\Phi}}{ }$ authors is admirably fitted to perform this task as he has intimate knowledge both of the practio 0 tioner's difficulties and the Ministry's requirements.

\section{A HISTOLOGY OF THE BODY TISSUES}

By Margaret Gillison. Pp. xiv +220 , with 103 illustrations. Edinburgh : E. \& S. Livingstone. 1950. I5s.

This little book describes most of the types of tissue in the human body and gives some account of their function and the kinds of way they are built into organs. Its author is lecturer in physiology at the I. M. Marsh College of Physical Education, Liverpool, and the book is aimed at medical auxiliaries such as physiotherapists.

It would serve also very well as an introduction to the background of their subject for histological technicians in training, for whom bigger books on histology are quite unsuited. The author's own illustrations are admirable.

B.L.

\section{GERMAN-ENGLISH MEDICAL DICTIONARY N}

By Joseph R. Waller, M.D., and Moritz KaAtz, 心 M.D., revised by Dr. Braitenburg. New 7th Edition. Pp. 244. London: George Allen and Unwin Ltd. I950. Ios.

A most useful little handbook for those whose $\stackrel{?}{+}$ German is not entirely reliable. It is recommended. 0

A.K.M. 